\title{
Postinflammatory and malignant protein patterns in aqueous humour
}

\author{
P. L. R. DIAS \\ From the Department of Physiology, Faculty of Medicine, University of Sri Lanka, Colombo
}

SUMMARY Normal aqueous humour and the aqueous humour of patients with cataract is virtually protein-free. Patients having retinoblastoma and non-malignant postinflammatory lesions show significantly high quantities of proteins in the aqueous humour. Retinoblastoma is associated with an increase in the globulin content and an albumin/globulin ratio below unity, while non-malignant postinflammatory intraocular conditions show a rise of the albumin fraction with an albumin/ globulin ratio above unity. It seems likely that the leakage of protein into the aqueous is different in the two conditions, and a transcellular route is postulated as being the cause in malignant conditions. The estimation of protein patterns in the aqueous humour may be of value in the diagnosis of intraocular malignancy.

The aqueous humour in man contains identifiable concentrations of protein whose components are identical to those of plasma, showing that the proteins of the aqueous humour are derived from the blood (Esser et al., 1954; François et al., 1958). Though all the plasma proteins are present in the aqueous, their absolute concentrations are very low. Niedermeier (1952) gave an average figure of $13 \mathrm{mg} / 100 \mathrm{ml}$, while Kronfeld (1941) showed that the protein content of human aqueous humour varied between 5 and $16 \mathrm{mg} / 100 \mathrm{ml}$ and that the amount of protein in a single sample of normal aqueous humour was between 15 and $45 \mu \mathrm{g}$. The concentration of protein is so small and its presence is detected with such difficulty that the aqueous humour is described as "virtually proteinfree' (Davson, 1962).

The proportions of the proteins in the aqueous differ from those in the plasma. The albumin fraction was nearly always higher, the gamma globulin fraction lower, and the albumin/globulin ratio higher in the aqueous than in the plasma (Kronfeld, 1941).

Since the discrepancy between the protein content of the aqueous and the plasma is so great, a breakdown in the blood-aqueous barrier will produce obvious effects on the protein concentration of the aqueous. It is known that after paracentesis the newly-formed aqueous is very rich in protein

Address for reprints: Dr P. L. R. Dias, Department of Physiology, Faculty of Medicine, University of Sri Lanka, Kynsey Road, Colombo 8, Sri Lanka
(Rohen, 1953). Staphylococcal infections of the eye increase the protein content of the aqueous, producing an albumin/globulin ratio of $\mathbf{2 \cdot 3}$ (Sallman and Moore, 1948). Wessely (1915) showed that irritation of the cornea produced a marked hyperaemia of the intraocular vessels, which was associated with an increased protein content of the aqueous humour. Inflammatory ocular conditions and disturbances of the blood-aqueous barrier therefore increase the permeability of the ocular capillaries, enabling large molecules to pass through the bloodaqueous barrier, and the albuminous exudate so formed gives rise to a plasmoid aqueous (DukeElder, 1970).

Little is known about changes in the blood aqueous barrier in malignant intraocular conditions. In certain malignant tumours the capillaries are poorly supported and protein leakage is a possibility (Florey, 1970), but there is no evidence that this is so in retinoblastoma. It is known, however, that many enzymes such as lactic dehydrogenase are increased in the aqueous humour in intraocular malignancy (Dias et al., 1971). Since all enzymes are proteins, the presence of excessive amounts of these enzymes in the aqueous is likely to produce an altered protein pattern in malignant conditions.

A non-inflammatory, non-malignant intraocular condition such as cataract, which is usually accompanied by a denaturation of the lens protein, is also likely to be associated with leakage of proteins through the lens capsule into the aqueous, producing a protein pattern different from that of the other two conditions. 
Table 1 Analysis of LDH activity, total protein, and protein pattern in malignant and post-inflammatory ocular lesions

\begin{tabular}{|c|c|c|c|c|c|c|c|c|c|}
\hline Diagnosis & $\begin{array}{l}\text { LDH activity } \\
\text { units } / 100 \mathrm{ml}\end{array}$ & $\begin{array}{l}\text { Total protein } \\
(\mathrm{g} / 100 \mathrm{ml})\end{array}$ & $\begin{array}{l}\text { Protein pat } \\
\text { Albumin }\end{array}$ & $\begin{array}{l}\text { tterns in } \\
\alpha_{1}\end{array}$ & $\begin{array}{c}g / 100 \mathrm{ml} \\
\alpha_{2}\end{array}$ & $\beta$ & $\gamma$ & $\begin{array}{l}\text { Total } \\
\text { globulin }\end{array}$ & $\begin{array}{l}\text { Albumin/globulin } \\
\text { ratio }\end{array}$ \\
\hline 1. Retinoblastoma & 3650 & $1 \cdot 4$ & $17 \cdot 9$ & $29 \cdot 9$ & nil & $22 \cdot 3$ & $29 \cdot 9$ & $82 \cdot 1$ & $0 \cdot 22$ \\
\hline 2. Retinoblastoma & 2360 & 0.9 & $17 \cdot 1$ & $17 \cdot 5$ & $20 \cdot 6$ & $34 \cdot 4$ & nil & $82 \cdot 5$ & $0 \cdot 20$ \\
\hline 3. Early phthisis & 490 & 0.4 & $66 \cdot 7$ & trace & trace & $16 \cdot 7$ & $16 \cdot 6$ & $33 \cdot 3$ & $2 \cdot 0$ \\
\hline 4. Keratomalacia & 170 & 0.8 & $58 \cdot 6$ & nil & nil & $20 \cdot 7$ & $20 \cdot 7$ & $41 \cdot 4$ & 1.4 \\
\hline 5. Adherent leucoma & 350 & $1 \cdot 8$ & $90 \cdot 8$ & nil & nil & $9 \cdot 2$ & nil & $9 \cdot 2$ & $9 \cdot 9$ \\
\hline
\end{tabular}

Little has been reported on the protein patterns in the aqueous humour in these conditions, and because the mechanisms of protein leakage and the nature of the proteins in the aqueous differ in these conditions, their protein patterns may also differ. It was therefore decided to study the protein patterns, total proteins, and the lactic dehydrogenase (LDH) activity in the aqueous humour of patients suffering from cataract and post-inflammatory and malignant lesions of the eye to determine whether differences exist in these conditions.

\section{Materials and methods}

Aqueous humour was collected by aqueous puncture from 10 patients who presented for cataract extraction at the Victoria Memorial Eye Hospital, Colombo. Two of these patients had a pseudoexfoliation of the lens capsule, 1 had a traumatic cataract, another had a cataract with a secondary glaucoma, while the rest all had hypermature senile cataracts.

Specimens of aqueous humour were also collected from 5 patients who presented for enucleation of their eyes. Two of these had retinoblastoma, which was subsequently confirmed histologically, while the other 3 patients, whose brief case histories are given below, had non-malignant post-inflammatory intraocular disorders.

Case 3 gave a history of a piece of firewood striking the eye, and, though treated for 2 months at the Eye Hospital, Colombo, showed a shrinking eye.

Case 4 was a patient with keratomalacia with an opaque cornea who had a painful blind eye.

Case 5 gave a history of a stone striking the eye 7 months previously, which resulted in the formation of an adherent leucoma, ending up finally as a secondary glaucoma.

The aqueous humour from all these patients was analysed within 2 hours of collection for LDH activity and total protein, and its protein pattern was determined by electrophoresis.

The LDH activity was estimated by the colori- metric method of King (1959), and expressed in units per $100 \mathrm{ml}$ of aqueous humour, a unit of activity being the amount of LDH which will reduce $1 \mu \mathrm{mol}$ lactate to $1 \mu \mathrm{mol}$ pyruvate in 15 minutes at $37^{\circ} \mathrm{C}$. This method was identical to that used earlier (Dias et al., 1971).

Paper electrophoresis was carried out on the samples of aqueous humour according to the method described by Wootton (1964) and the total proteins were estimated by the Biuret method.

\section{Results}

The aqueous humour from the 10 patients with cataract showed no trace of protein on electrophoresis, and the highest protein content recorded was $0 \cdot 17 \mathrm{~g} / 100 \mathrm{ml}$ from a patient with senile cataract. The LDH activity of the aqueous humour in all these patients ranged between 140 and 360 units per $100 \mathrm{ml}$. This is within the normal limits for LDH activity in non-malignant intraocular conditions (Dias et al., 1971).

The analysis of the protein patterns and the LDH activity of the 5 patients suffering from postinflammatory and malignant lesions is shown in Table 1. The electrophoretic patterns of these patients are shown in Figs. 1 and 2.

\section{Discussion}

Although normal aqueous humour is virtually protein-free, it was thought likely that in patients with cataract with damage to the lens capsule denatured lens protein would leak into the aqueous. The above results show that even with damage to the lens capsule leakage of proteins into the aqueous is minimal, for in none of these patients could even traces of protein be detected in the aqueous on electrophoresis, and the total protein content of the aqueous was low.

Though the total protein content of the aqueous in malignant and post-inflammatory conditions is significantly higher than normal (Table 1), there appears to be no significant difference $(P=0 \cdot 1)$ in 
the total amount of protein leaking into the aqueous in post-inflammatory and malignant intraocular conditions.

Analysis of the protein patterns shows that in the 2 patients with retinoblastoma the total globulins

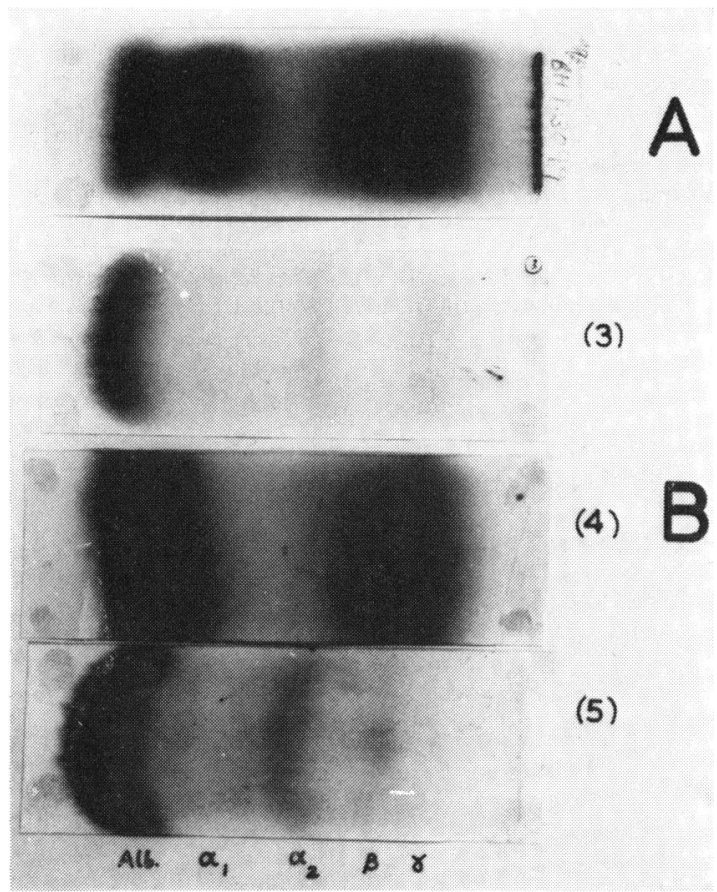

Fig. 1 Electrophoretic patterns of specimens of aqueous humour (run for 16 hours at a pH 8.6). (A) Patient (1) with retinoblastoma. (B) Three patients with postinflammatory non-malignant ocular lesions

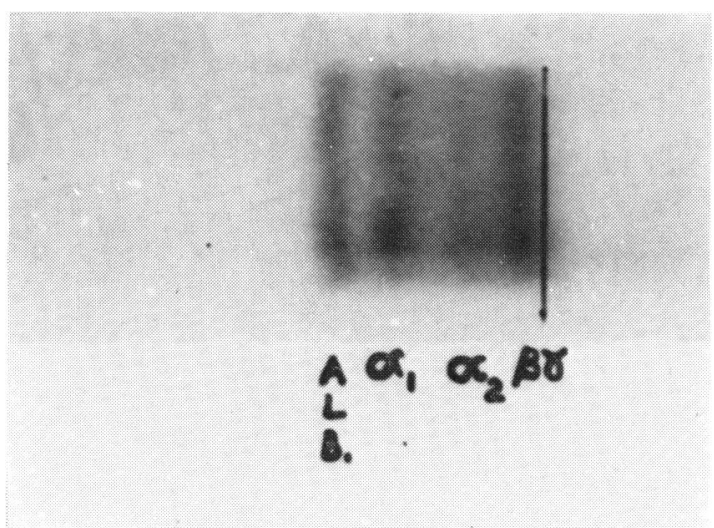

Fig. 2 Electrophoretic pattern of specimen of aqueous humour from retinoblastoma patient (2) (run for 4 hours at a $\mathrm{pH} 8 \cdot 6$ ) are raised, with a corresponding lowering of the albumin fraction, while the 3 patients with nonmalignant post-inflammatory eye lesions show an increase of the albumin fraction. A noticeable feature was the absence of alpha-1 and alpha-2 globulins in the aqueous humour of the 3 postinflammatory lesions.

The albumin/globulin ratio in the 2 patients with malignant lesions is below unity, while in the nonmalignant conditions the ratio is above unity.

As the albumin fraction is not increased in the patients with malignant lesions, it appears likely that the mechanism of protein leakage in malignant conditions is not due to a breakdown of the bloodaqueous barrier, for, if the protein leakage was due to an increase in the permeability of the ocular capillaries, albumin would be the first protein to leak out and its concentration would be highest.

It is known that malignant cells secrete enzymes like LDH into the surrounding body fluid and that the lactic dehydrogenase activity is primarily a globulin component which does not readily exchange with the plasma constituent (Wroblewski, 1957). The globulin fraction in the aqueous humour in retinoblastoma was more than double the globulin fraction in the post-inflammatory conditions. It has also been shown that high concentrations of metabolites from the retinal nerve plexuses pass by forward diffusion through the vitreous into the aqueous humour (Dias and Amarasiri, 1978). The LDH activity of the aqueous was raised in retinoblastoma, while it was within normal limits in the post-inflammatory conditions. As the LDH activity is grossly increased in retinoblastoma, it seems likely that these enzymes and other cellular metabolic products released by malignant cells and diffusing forwards are the reasons for the increase in protein in the aqueous humour in retinoblastoma. It is postulated that the increase in protein in intraocular malignant tumours is due to a transcellular protein leak rather than a transcapillary leak.

As differences exist in the protein pattern of the aqueous humour in cataract and post-inflammatory and malignant lesions of the eye, it seems likely that the determination of the electrophoretic protein pattern in the aqueous humour might be of value in the diagnosis of intraocular malignancy.

I thank Dr S. Senthe Shanmuganathan and Dr C. Peiris for their assistance, and the University of Sri Lanka for financial support.

\section{References}

Davson, H. (1962). The intraocular fluids. In The Eye, Vol. 1, p. 104. Academic Press: New York.

Dias, P. L. R., Senthe Shanmuganathan, S., and Rajaratnam. 
M. (1971). Lactic dehydrogenase activity of aqueous humour in retinoblastoma. British Journal of Ophthalmology, 55, 130-132.

Dias, P. L. R., and Amarasiri, A. A. (1978). 4-Hydroxy-3methoxymandelic acid excretion in retinoblastoma. British Journal of Ophthalmology, 62, 525-527.

Duke-Elder, S. (1970). The physiology of the eye. In Parson's Diseases of the Eye, 15th edn., p. 15. Churchill: London.

Esser, H., Heinzler, F., and Pau, H. (1954). Elektrophoretische Trennung der Eiweissfraktionen im menschlichen Kammerwasser. Albrecht von Graefes Archiv für Ophthalmologie, 155, 11-16.

Florey, H. W. (1970). In General Pathology, 4th edn., p. 676. Lloyd Luke: London.

François, J., Rabaey, M., and Evens, L. (1958). Agar microelectrophoresis of the aqueous humour. Archives of Ophthalmology, 59, 692-702.

King, J. (1959). A routine method for the estimation of lactic dehydrogenase activity. Journal of Medical Laboratory Technology, 16, 265-272.
Kronfeld, P. L. (1941). Protein content of the aqueous humour in man. American Journal of Ophthalmology, 24 1121-1131.

Niedermeier, M. (1952). Quantitative Eiweissfraktionierung des Kammerwassers. Klinische Monatsblätter für Augenheilkunde, 120, 644-645.

Rohen, J. (1953). Die Gestalt der Blutkammerwasserschranke beim Kaninchen in Ruhe und nach funktioneller Belastung. Berichte der Deutschen Ophthalmologischen Gesellschaft, 58, 65-70.

von Sallman, L., and Moore, D. H. (1948). Electrophoretic patterns of concentrated aqueous humour of the rabbit, cattle and horse. Archives of Ophthalmology, 40, 279-284.

Wessely, K. (1915). Weitere Beitrage zur Lehre vom Augendruck. Archiv für Augenheilkunde, 78, 247-278.

Wroblewski, F. (1957). Clinical significance of alterations in lactic dehydrogensase activity of body fluids. American Journal of Medical Science, 234, 301-309.

Wootton, I. D. P. (1964). In Microanalysis in Medical Biochemistry, 4th edn., p. 147. Churchill: London. 